\title{
A Comparative Study on "Technical and Vocational" Education of Taiwan and Transformation of Application-oriented University of Fujian
}

\author{
Lihua Huang \\ Fuzhou University of International Studies and Trade \\ Fuzhou, China
}

\author{
Shaofeng Luo \\ Fuzhou University of International Studies and Trade \\ Fuzhou, China
}

\begin{abstract}
Based on the study of the higher education system of Taiwan and higher technical and vocational education system of Taiwan, it puts forward some suggestions on the innovation of transformation of application-oriented colleges and universities of Fujian in this paper, such as the teaching reform, the teaching organization and school-running model of international cooperative education.
\end{abstract}

Keywords-"technical and vocational" education of Taiwan; application-oriented university; school-running model

\section{INTRODUCTION}

The "technical and vocational" education of Taiwan covers many aspects, such as the cultivation of students' selfconcept, the study of personal vocational interests and development, and the training of pre-employment education in professional field. It also enhances the technical capacity and professional quality of the students for market demand. And it reserves the ability to exchange work. The types include the system of vocational school, the system of comprehensive high school, the system of junior college (five-year-diploma education, two-year-diploma education), the system of technical college (four-year-program students, two-year-program students) and the system of university of science and technology (four-year-program students, twoyear-program students, master, doctor). Technical and vocational schools at all levels provide opportunities for personal growth and development. They cultivate the technical manpower required by the society, promote social changes, and enhance the core competitiveness of the nation.

\section{SURVEY OF HIGHER EDUCATION SYSTEM OF TAIWAN}

The education development of Taiwan is diversified. Generally, it can be divided into parallel-tracking two systems of ordinary education and technical and vocational education. And the students have more choices. During the period, students can change the learning channels. At all levels, no matter the students are in the general education system or technical and vocational education system, they can continue to learn with corresponding channels. Taiwan

Project Fund: A comparative study on "technical and vocational" education of Taiwan and transformation of application-oriented university of Fujian, "13th five-year plan" of education and science of Fujian province of 2016 annual project. Project Number: FJJKCGZ16-418 has established a system of technical and vocational education (higher vocational school-junior collegetechnical college-university of science and technology). Higher vocational and technical education is an important part of the consistent system of technical and vocational education. It covers junior colleges, technical colleges and universities of science and technology and other technical and vocational education institutions. After junior high school, two systems have parallel-tracking development. Technical and vocational education and general education began to divert from each other. The students who choose the technical and educational system would experience the pattern of higher vocational school-junior collegetechnical college - university of science and technology. The students who select the general higher education system would go through another pattern of ordinary high schoolordinary colleges and normal universities and so on. The two departments of education administration are supervised by the competent departments. Respectively, they are the bureau of higher education (higher education division) and the bureau of technical and vocational education (technical and vocational education division). The systems of ordinary higher education and higher technical and vocational education have parallel-tracking development. At the same time, these two systems are connected by Overpass Bridge. They are known as two highways of the education system of Taiwan.

\section{TO STUDY THE SYSTEM OF HIGHER "TECHNICAL AND VOCATIONAL" EDUCATION OF TAIWAN}

Taiwan has attached importance to the development of technology and vocational education for a long time. With the economic and industrial development, the system of higher technical and vocational education is relatively complete. In the type, there are day-time department and the department of continuing education. The day-time department and the department of continuing education are equivalent to the full-time education and adult education of the mainland, and the day-time department is the key part to explore higher technical and vocational education. With the frame between two educational channels, the original summative technical and vocational education would be smooth in the end. 
At present, the technical and vocational education system has covered the secondary technical and vocational education and advanced technical and vocational education, and has gone through many levels of higher vocational college, junior college, undergraduate, master and doctor. And the system is perfect.

In senior high school, the technical and vocational education is implemented by the agricultural, industrial, commercial, aquatic, medical and other types of higher vocational schools. Higher vocational schools of Taiwan are different from the junior colleges of the mainland. Higher vocational school courses have many types with the different types of school. However, they are usually divided into general subjects, professional basic subjects, professional compulsory subjects, professional internships and activities and other subjects.

In junior college, the technical and vocational education is provided by the five-year junior college and two-year junior college. Five-year junior college recruits junior high school graduates. And they need to have class for five years (some students of a few professionals need six years). Twoyear junior college recruits high school graduates, and they need to have class for two years. These schools are also established on the principle of classification, such as agriculture, industry, business and other institutions. "Junior College Law" was revised in 1987. It proposed the principle of "to teach the application-oriented science and technology, to cultivate practical professionals". And this principle is used in junior colleges.

In the stage of undergraduate colleges or above, the technical colleges and the universities of science and technology are responsible for the technical and vocational education. Technical college and university of science and technology can be regarded as the colleges and universities of science and technology. These two types of technical college and junior colleges are often regarded as "junior technical colleges" or "technical and vocational colleges". Actually, they include four-year technical education and twoyear technical education. At present, four-year technical education is the main body of technical colleges. The number of students of two-year technical colleges dropped sharply with the corresponding reduction in size. Technical college and universities of science and technology would undertake the technical and vocational education of postgraduate and above level, including master degree candidates and doctoral candidates. At present, many universities of science and technology have established research institutions to help master, doctoral students have technical and vocational education, including some outstanding private universities with academic performances. In the early period, it didn't have independent, complete higher technical and vocational education system in Taiwan. Aside from the length of study, there is no significant difference between the education of junior college and undergraduate education. This feature of early higher education is very similar to the education of the mainland. The training goal of junior college is close to the training goal of undergraduates. And the courses of junior college are the "compressed biscuit" of bachelor course.

\section{THE INNOVATION OF SCHOOL-RUNNING MODEL OF APPLICATION-ORIENTED UNIVERSITIES OF FUJIAN}

\section{A. Carry out Research on Teaching Reform, Advocate Interactive Teaching}

The German educator, Diesterweg said: "The art of teaching lies not only in teaching skills, but also on the encouragement, awakening and inspiration". Actually, teaching is an art. The teachers are the sculptors. Facing the educational objects, the teachers need to study hard the ways of "carving". In order to promote the teaching skills of teachers, colleges and universities have adopted a series of measures to promote the reform and innovation of education and teaching. Undergraduate students have distinct group characteristics, and their learning motivation is often derived from interests. It requires high demands for teachers' teaching. And it requires teachers to interact with students in teaching process. And then, it may improve the students' interests in learning. In order to achieve this purpose, undergraduate colleges and universities advocate interactive teaching, organize the majority of teachers to carry out researches on teaching methods, and promote innovation in teaching mode.

1) The colleges organize the competition of basic skills every year, and it can improve teachers' teaching skills by observing the seminar: Undergraduate colleges and universities organize the competition of basic teaching skills of young teachers. According to the observation of the teaching, reviews of senior teachers, students' evaluation, mutual exchange and other aspects, the participating teachers have to undergo baptism of rigorous scholarship and dedication spirit. It is also strict training for teaching skills. A group of outstanding teaching young teachers stand out from each game. And they have played good roles in the teaching process. Also, these young teachers have led the improvement of the overall teaching quality of undergraduate colleges and universities.

2) The colleges could use modern means of education, actively promote multimedia teaching, and improve teaching effectiveness: Undergraduate colleges and universities have always attached great importance to the construction of hardware and software resources of teaching information technology. The teachers can effectively manage the courses, make the content of the courses, generate homework and enhance collaboration by making the network platform with the investment. On the network platform, it has five models of convenient and practical "teaching resources", "course exchange tool", "course management", "test examination management" and "system management". On the platform, the teachers can organize and manage the teaching and even make remote teaching. The students can get a variety of information and learning materials. Also, they can have learning, examinations and other activities online. And then, it may achieve online teaching objectives. Teachers and students can have interactive communication and Q \& A through the platform 
with unlimited time and place. Through the platform, the teachers can build network courseware. It has greatly promoted the teaching quality. Undergraduate colleges and universities would provide multimedia technology training for the teachers every year. With the application of multimedia technology, the picture and its accompanying essay are both excellent in the classroom teaching. And it's static and dynamic combination. Also, the content of the teaching course is vivid. The content has large amount of information. Many contents which are difficult to describe in the classroom teaching, they can be visually demonstrated through the pictures, animation, video and other media.

3) Create publications, provide educational reform and innovation platform: In order to create a platform for teaching reform and exchange for teachers, colleges and universities can set up journals to publicize the guiding ideology and educational philosophy, and exchange educational teaching and research achievements. It would be helpful for teaching research and teaching reform of undergraduate colleges and universities. These journals mainly publish the latest research achievements of education and teaching. Also, these journals publish paper or research reports on teaching theory, teaching reform, education management, teacher construction and other aspects of undergraduate college teachers. And these journals can timely convey teaching information and dynamics of undergraduate colleges and universities.

\section{B. To Innovate Teaching Organization and Guide the Investigative Study}

1) Create conditions for the implementation of smallclass teaching: Small-class teaching has high requirements for the use of resources. And it is suitable to carry out with a few of students and relatively large teaching space. However, the small-class teaching can fully mobilize the enthusiasm, initiative, participation and creativity of students to learn. It can give full play to the role of class group. And then, it would promote students to make selflearning and multi-communication. Then, it would improve learning outcomes. Undergraduate colleges and universities encourage the branches to carry out small-classes teaching in the case of conditions permitting.

2) The implementation of large-class teaching and small-class tutorship: Due to the resource constraints, the majority of undergraduate colleges and universities have to arrange large-class teaching. Undergraduate colleges and universities encourage the branch institutes to carry out large-class teaching and small-class tutorship in some courses. These colleges and universities can take this way like that the students can have theory course in large classes, and they would have group counseling after class. In addition to the faculty adviser, undergraduate colleges and universities also select some outstanding senior students as course counselors. In remedial lessons, the students can make full use of the network platform to complete a large number of exercises, and use accounting laboratories to carry out simulation practice. As the assistants, the senior students can also further consolidate the knowledge to guide lower school students to learn. It would achieve two things at one stroke. With the implementation of small-class tutorship, it can provide learning and discussion opportunities for the students. It can help students deepen the understanding and mastery of knowledge. And then, it would improve teaching effectiveness.

3) Focus on reform assessment methods, pay attention to the practical application of knowledge: Scientific and reasonable curriculum assessment methods can stimulate learning initiatives of students, enhance the ability to master and use knowledge, and improve students' learning outcomes. In recent years, undergraduate colleges and universities encourage teachers to make curriculum reform methods with the actual courses and improve the assessment methods of students' achievements under the premise of meeting the requirements of the assessment. It shows the basic idea of reform. The colleges and universities can make teaching reform from the assessment of students' mastery of knowledge to comprehensive study of students' practical ability to solve problems with their knowledge, as well as collaboration, exploration and innovation. And the exams can be extended from the final exam to the general tests. The colleges and universities should strengthen the examination of the students' learning process, increase the proportion of the great assignment, paper, class discussion and demonstration, experiment operation online, the results of ordinary tests, and reduce the proportion of the final exam result of the total. And they also should reduce the pressure of the exam on the students, and change the bad habits of surprise review of some students. For example, they could have the assessment of students' study of the computer. It can increase the usual tests and the machine tests. The formula also could be printed on the test paper. It wouldn't test the parrot knowledge. It mainly focuses on the actual ability of students.

\section{Implement International Cooperative Education Programs, and Enhance the International \\ Competitiveness of Students}

In school-running practice, undergraduate colleges and universities continuously expand the channels of international exchanges. Through joint running of schools, joint courses, short-term exchanges, cooperative research and other forms, they can actively carry out international education cooperation. And then, they can learn advanced education philosophy and teaching management model of foreign universities. The students also can expand international vision. Finally, they can improve the ability to participate in international competition. With the economic and social development, China has been constantly integrating into the world. And China has been influenced by international community greatly. Higher education must take the road of international cooperation and exchanges. The trend is inevitable. Through the international cooperation in 
running schools, the colleges can directly study advanced teaching philosophy, teaching content, teaching methods, professional curriculum, administration and advanced experience of student management of overseas higher education. These colleges should continuously improve the teaching quality, enhance the core competitiveness of students, and cultivate the talents with innovative spirit and international vision.

\section{CONCLUSION}

With the development of external social and economic environment and the transformation of internal higher education environment, the development of higher technical and vocational education in different stages of Taiwan is different. Since the middle of 1990s, with the large-scale promotion of new technical colleges and universities of science and technology, the number of technical colleges has been reducing sharply. Technical colleges and universities of science and technology become the focus in the development of higher technical and vocational education. The study of higher technical and vocational education of Taiwan is conducive to the innovation of school-running model of application-oriented university of Fujian.

\section{REFERENCES}

[1] Ying Lina. Analysis on discipline construction of local applicationoriented colleges and universities based on SWOT [J]. Applicationoriented Higher Education Research, 2015.

[2] Ji Huixiang. Problems and countermeasures of discipline construction in newly-built and application-oriented undergraduate colleges [J]. Education Modernization, 2016.

[3] Hao Chuanbo. To deepen the cooperation between schools and enterprises and improve the training quality of application-oriented talents [J]. Value Engineering, 2016. 